\title{
Exposure of cetaceans to petroleum products following the Deepwater Horizon oil spill in the Gulf of Mexico
}

\author{
Laura Aichinger Dias ${ }^{1,2, *}$, Jenny Litz ${ }^{2}$, Lance Garrison ${ }^{2}$, Anthony Martinez ${ }^{2}$, \\ Kevin Barry ${ }^{3}$, Todd Speakman ${ }^{4,5}$
}

\author{
${ }^{1}$ Cooperative Institute for Marine and Atmospheric Studies (CIMAS), University of Miami, 4600 Rickenbacker Causeway, \\ Miami, Florida 33149-1098, USA \\ ${ }^{2}$ National Oceanic and Atmospheric Administration, National Marine Fisheries Service, Southeast Fisheries Science Center, \\ 75 Virginia Beach Drive, Miami, Florida 33149, USA \\ ${ }^{3}$ National Oceanic and Atmospheric Administration, National Marine Fisheries Service, Southeast Fisheries Science Center, \\ 3209 Frederic Street, Pascagoula, Mississippi 39567, USA \\ ${ }^{4}$ Jardon \& Howard Technologies Incorporated (JHT Inc.), 2710 Discovery Dr., Suite 600, Orlando, Florida 32826, USA \\ ${ }^{5}$ National Oceanic and Atmospheric Administration, National Centers for Coastal Ocean Science, \\ Hollings Marine Laboratory, 331 Fort Johnson Road, Charleston, South Carolina 29412, USA
}

\begin{abstract}
The Deepwater Horizon (DWH) oil spill was by far the largest offshore oil spill in the history of the USA. For $87 \mathrm{~d}$, the well spilled millions of barrels of oil into the Gulf of Mexico, extensively affecting the habitat of numerous species of cetaceans. Previous studies have suggested that cetaceans would be able to detect and avoid oiled waters and, when in contact, oil would not adhere to their slick skin. However, photographic evidence and field observations gathered following the DWH oil spill documented at least 11 cetacean species swimming through oil and sheen, with oil adhered to their skin. This study not only documented direct exposure of cetaceans to petroleum products but also the persistence of the oil on their skin. In addition, given the extent of the DWH oil spill, the number of affected species and individuals was likely far greater than the documented occurrences captured during this study. Based on this evidence, we suggest that during oil spills in cetacean habitat, direct exposure of whales and dolphins to petroleum products will likely occur and should therefore be taken into account during response activities and damage assessments.
\end{abstract}

KEY WORDS: Cetacean · Oil exposure $\cdot$ Deepwater Horizon · Oil spill $\cdot$ Petroleum

\section{INTRODUCTION}

Between 20 April and 15 July 2010, the Deepwater Horizon (DWH) incident spilled millions of barrels of oil into the Gulf of Mexico (hereafter referred to as the GoM), extensively affecting the known habitat of multiple species of cetaceans (Dias \& Garrison 2015, DWH NRDA Trustees 2016). Previous studies have suggested that some cetacean species are able to

${ }^{*}$ Corresponding author: laura.dias@noaa.gov detect and avoid oiled waters. However, detection seemed to depend on oil thickness and color during experiments in captivity and observations in the wild. Testing with captive bottlenose dolphins Tursiops truncatus showed that animals could detect darker and thicker oils (ranging from crude to mineral oils) on the surface of the water but could not easily (if at all) detect lighter and lightly-colored fractions (such as sheen and gasoline) (Geraci et al.

(C) L. Aichinger Dias, T. Speakman, and (outside the USA) the US Government 2017. Open Access under Creative Commons by Attribution Licence. Use, distribution and reproduction are unrestricted. Authors and original publication must be credited.

Publisher: Inter-Research · www.int-res.com 
1983). In the wild, Smultea \& Würsig (1995) reported that bottlenose dolphins appeared to have detected thick oil (like mousse, a thicker, dark brown, frothy oil) as they hesitated but still entered an oil slick, but did not appear to detect sheen during the Mega Borg oil spill, which also occurred in the GoM (Smultea \& Würsig 1995).

Under experimental conditions, bottlenose dolphins avoided swimming beneath a slick of $1 \mathrm{~cm}$ thick, colored, non-toxic mineral oil, indicating that the oil slick functioned as a barrier to reaching uncontaminated areas of the pen (Smith et al. 1983). In the wild, however, levels of avoidance appear to vary as bottlenose dolphins were invariably observed swimming through oiled areas (Smultea \& Würsig 1995), and killer whales Orcinus orca were documented in heavy sheens of oil or mousse during the Exxon Valdez oil spill in Alaska (Matkin et al. 2008).

Unlike with sea otters and pinnipeds, oil would not be expected to adhere well to the surface of cetacean skin due to the lack of hairs and the frequent sloughing of skin cells (Engelhardt 1983, Helm et al. 2015). In addition, oil should not readily penetrate cetacean skin due to tight intercellular bridges and thick epidermis (O'Hara \& O'Shea 2001). Nevertheless, cetaceans can be exposed to oil and other toxic petroleum compounds through direct contact with the eyes, mouth (ingestion), and airways (inhalation), potentially leading to inflammation and lung congestion (Geraci \& St. Aubin 1990).

There are few published observations of wild cetaceans in or near petroleum products and none that have documented oil adherence to their skin. The goal of this study was to compile evidence of cetaceans' exposure to petroleum products (oil and/ or sheen) in the GoM following the DWH oil spill.

\section{MATERIALS AND METHODS}

\section{Cetacean targeted projects}

Immediately after the explosion of the DWH wellhead on 20 April 2010, the Natural Resource Damage Assessment (NRDA) through the National Oceanic and Atmospheric Administration (NOAA) began several projects which documented cetaceans in the affected offshore and coastal areas of the GoM. NOAA NRDA projects began by 28 April, with marine mammal observer teams systematically recording cetaceans in petroleum products by means of opportunistic field notes (descriptions of oil and/or sheen on the surface of the water during cetacean sightings) and photographs (cetaceans photographed swimming in petroleum products or with oil adhered to their skin) collected during these surveys. Cetacean sightings consisted of one or more individuals of a whale or dolphin species (or unidentified cetacean) observed in the same general location and time. As part of the survey protocol, the observers also estimated the number of individuals in each sighting. The Helicopter Survey departed out of Houma, Louisiana, mainly surveying the area around the DWH spill site from 28 April until 14 July (NOAA NRDA 2015). The surveys were flown at low altitude (600 feet) and the presence or absence of oil and sheen were systematically recorded during all cetacean sightings following guidelines on the Open Water Oil Identification Job Aid for aerial observation (OWJA 2007); opportunistic photographs were also taken. The Synoptic Twin Otter Survey departed out of Mobile, Alabama, surveying from the Mississippi River Delta to the western Florida Panhandle, including the DWH spill site, between 28 April and 2 September (Garrison 2011). Cetacean sightings and petroleum products were systematically recorded throughout this survey but independently from each other; opportunistic field notes and photographs were also taken. A shipbased survey, the Marine Mammal Oil Spill Assessment Survey (MaMOSAS cruise), was conducted between 16 June and 8 August with the main goal of documenting habitat use and distribution of oceanic cetaceans in the north-central GoM and around the DWH site (Martinez et al. 2010). Sightings were recorded throughout the survey and opportunistic field notes and photographs of cetaceans in oil and/or sheen were also collected. Lastly, photo-identification surveys of bottlenose dolphins (Mississippi Sound [MSS] NRDA Photo-ID Survey) were conducted intermittently in Mississippi Sound from June 2010 through May 2012 (DWH NRDA Trustees 2016).

\section{Oil spill response and monitoring activities}

In addition to the targeted cetacean surveys mentioned above, opportunistic photographs of cetaceans swimming in oil and/or sheen were collected during spill response and monitoring activities by the NOAA, the Louisiana Department of Wildlife and Fisheries (LDWF) and the United States Coast Guard (USCG). Throughout the oil spill and as response activities intensified, these agencies deployed their 
personnel and resources and assisted each other in documentation and management of wildlife, such as marine mammals and sea turtles, in the affected offshore and coastal waters of the GoM (DWH NRDA Trustees 2016).

\section{Cetacean stranding data}

Evidence of direct exposure was also gathered from examination of stranded cetaceans with oil on their bodies. Associated photographs were collected by volunteer stranding network agencies along the GoM's shoreline (Stout 2015, MMHSRP 2015).

\section{Data access and analyses}

Cetacean sighting databases including field notes collected during the Helicopter Survey, the Synoptic Twin Otter Survey, and the MaMOSAS cruise were held at and acquired directly from NOAA's Southeast Fisheries Science Center (SEFSC) in Miami, Florida. In this location, the databases were searched for field notes made by the marine mammal observers on the presence of petroleum products during cetacean sightings. Photographs taken during the MaMOSAS cruise were also searched for obvious signs of oiling in the water or on the bodies of cetaceans, following OWJA (2007) guidelines. The photographs taken during the MSS NRDA Photo-ID Survey and by the LDWF were obtained from the National Centers for Coastal Ocean Science (NCCOS), Hollings Marine Laboratory in Charleston, South Carolina. In this location, T. Speakman queried all sightings from the MSS photo-identification database in which (1) oil was observed in water or (2) observations of oil on dolphins were described in the field notes. He also reviewed all photos from queried 'oil' sightings and selected the photos of dolphins with oil on their bodies. Photographs taken during spill response and monitoring activities, the Helicopter Survey, and the Synoptic Twin Otter Survey were searched with and acquired through 'PhotoLogger', a photo management application used for site documentation of the DWH oil spill maintained by NOAA's Office of Response and Restoration (ORR). In PhotoLogger, L. A. Dias searched for photographs of cetaceans in oil using keywords (e.g. whale, dolphin, marine mammal), date of known operations that reported cetaceans (e.g. USCG overflights), or known sources of the photos (e.g. photographer's name). Spreadsheets containing date, location, file name, and other comments were provided with each search. The comment section of some records provided the species and information on the petroleum products present in the moment the photo was taken. If these data were not available, cetologists at the SEFSC independently identified the species and L. A. Dias inferred the substances from the photographs as sheen or oil according to the OWJA for aerial observation (OWJA 2007).

Chemical fingerprinting analysis of external wipe samples collected from stranded animals by the Marine Mammal Stranding Network confirmed cases of dolphins with oil consistent with the DWH spill adhered to their bodies in Louisiana and the Florida Panhandle (Stout 2015). The individual stranding records and photographs were accessed by L. A. Dias through the Marine Mammal Health and Stranding Response Program National Database (MMHSRP 2015).

\section{RESULTS}

\section{Documented direct oil exposure}

The evidence presented here does not necessarily represent a complete record of all possible occurrences of cetaceans in oil and/or sheen following the DWH spill, but rather those obtained through the search methods outlined above. From all of the data sources described, 85 occurrences of cetaceans swimming in or near petroleum products, or with oil adhered to their bodies were recorded between April 2010 and February 2012 (Table 1, Fig. 1). Each occurrence involved one or more individuals with evidence of exposure to oil and/or sheen at a specific location and time recorded during the targeted cetacean surveys (cetacean sightings from NOAA NRDA projects including filed notes and photos), during oil spill response and monitoring activities (opportunistic photographs) and from records of stranded cetaceans. Of the 21 species of cetaceans regularly seen in the GoM (Dias \& Garrison 2015), the occurrences involved 11 species and 2 categories of unidentified cetaceans: Atlantic spotted dolphin Stenella frontalis, bottlenose dolphin Tursiops truncatus, Cuvier's beaked whale Ziphius cavirostris, pantropical spotted dolphin Stenella attenuata, pygmy sperm whale Kogia breviceps, Risso's dolphin Grampus griseus, rough-toothed dolphin Steno bredanensis, sperm whale Physeter macrocephalus, spinner dolphin Stenella longirostris, striped dolphin 
Table 1. Documented occurrences of direct exposure of cetaceans to petroleum products following the Deepwater Horizon (DWH) oil spill. SEFSC: Southeast Fisheries Science Center; NCCOS: National Centers for Coastal Ocean Science; MaMOSAS: Marine Mammal Oil Spill Assessment Survey; MSS NRDA: Mississippi Sound Natural Resource Damage Assessment; NOAA: National Oceanic and Atmospheric Administration; USCG: United States Coast Guard; LDWF: Louisiana Department of Wildlife and Fisheries; MMHSRP: Marine Mammal Health and Stranding Response Program

\begin{tabular}{|c|c|c|c|}
\hline Project & Type of evidence & Source of evidence & $\begin{array}{c}\text { No. of } \\
\text { occurrences }\end{array}$ \\
\hline \multirow[t]{2}{*}{ Helicopter Survey } & Photographic & PhotoLogger & 2 \\
\hline & $\begin{array}{l}\text { Substance systematically recorded } \\
\text { during sightings }\end{array}$ & SEFSC Miami & 45 \\
\hline \multirow[t]{2}{*}{ Synoptic Twin Otter Survey } & Opportunistic field note (no photo) & SEFSC Miami & 5 \\
\hline & Photographic & PhotoLogger & 1 \\
\hline \multirow[t]{2}{*}{ MaMOSAS cruise } & Opportunistic field note (no photo) & SEFSC Miami & 3 \\
\hline & Photographic & SEFSC Miami & 6 \\
\hline MSS NRDA Photo-ID Survey & Photographic & NCCOS Charleston & 3 \\
\hline $\begin{array}{l}\text { Spill response and monitoring } \\
\text { activities by NOAA }\end{array}$ & Photographic & PhotoLogger & 3 \\
\hline $\begin{array}{l}\text { Spill response and monitoring } \\
\text { activities by USCG }\end{array}$ & Photographic & PhotoLogger & 2 \\
\hline $\begin{array}{l}\text { Spill response and monitoring } \\
\text { activities by LDWF }\end{array}$ & Photographic & NCCOS Charleston & 1 \\
\hline Strandings & $\begin{array}{l}\text { Oil fingerprinted to the DWH oil spill } \\
\text { and photographs }\end{array}$ & $\begin{array}{l}\text { Stout (2015), } \\
\text { MMHSRP (2015) }\end{array}$ & 14 \\
\hline Total & & & 85 \\
\hline
\end{tabular}

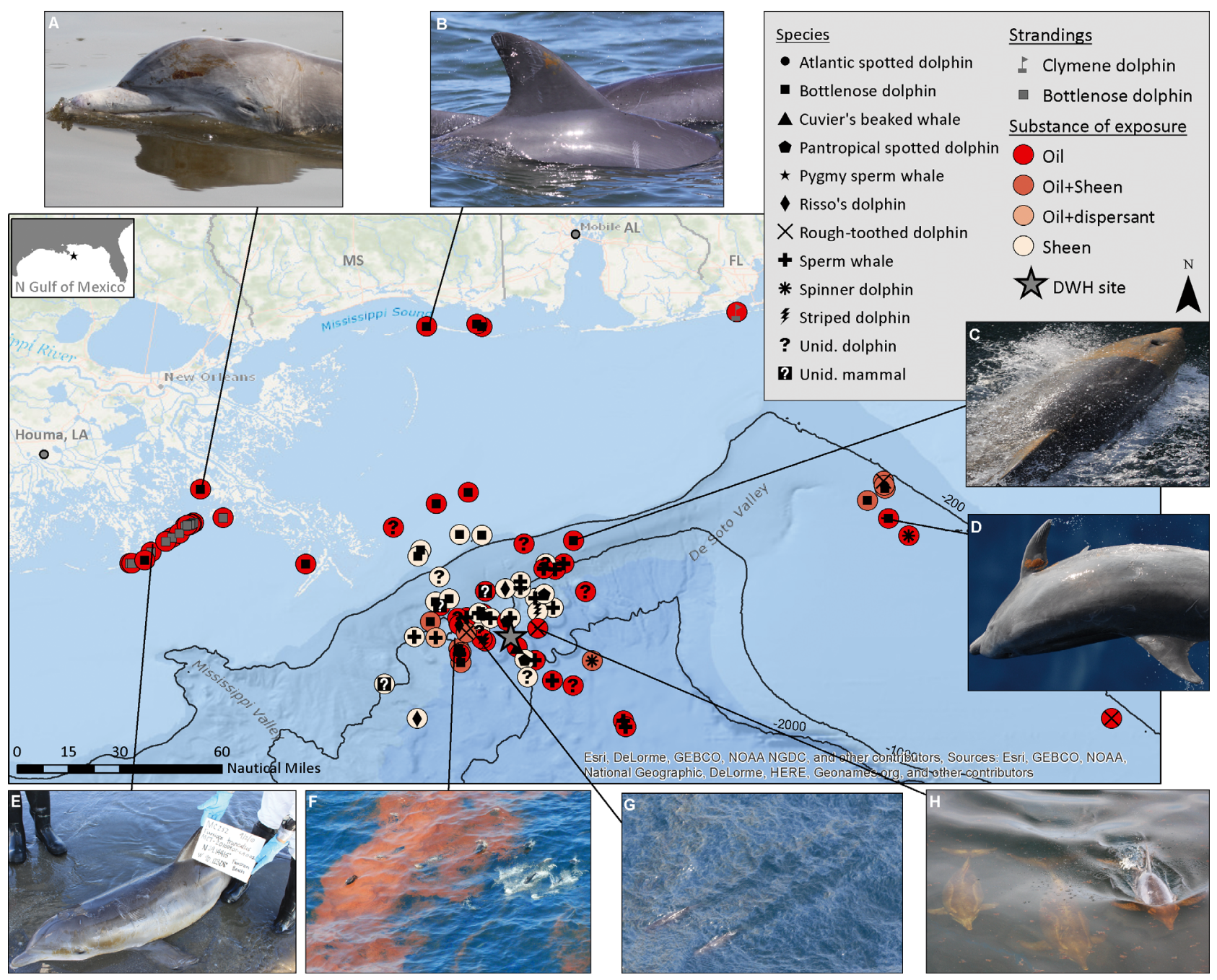


Stenella coeruleoalba, Clymene dolphin Stenella clymene, and unidentified dolphin and mammal (Fig. 1). During the Helicopter Survey, over $70 \%$ of the 66 cetacean sightings were recorded in oil and/or sheen $(\mathrm{n}=47)$, including 2 sightings with photographs. Field notes and photographs collected during the Synoptic Twin Otter Survey, the MaMOSAS cruise, and the MSS NRDA Photo-ID Survey provided 18 occurrences of evidence of direct exposure. Teams monitoring oil spill response activities (NOAA, LDWF and USCG) opportunistically recorded an additional 6 occurrences. Finally, weathered oil consistent with the DWH spill was detected in 13 dolphins that stranded in Louisiana (2 live and 11 dead) and 1 live stranding recorded in the Florida Panhandle between May 2010 and February 2012 (Stout 2015) (Table 1).

\section{Potential exposure to the oil footprint}

In addition to the direct oil exposure documented, circumstantial evidence of exposure to oil was obtained by overlapping the cetacean sightings recorded during the Helicopter Survey, the Synoptic Twin Otter Survey and the MaMOSAS cruise with the Synthetic Aperture Radar (SAR) satellite imagery of the oil (i.e. oil footprint). The oil footprint was obtained from the NOAA's Environmental Response Management Application (ERMA) website and is a polygon of the presence of oil for one or more days captured between 24 April and 11 August 2010 (ERMA 2014). A total of 510 cetacean sightings involving over 6400 individuals overlapped with the oil footprint between 28 April and 10 August 2010 (Fig. 2), including most of the occurrences with documented direct exposure described above. The sightings without documented direct exposure but registered within a similar time frame of the oil footprint indicated a potential encounter with oil, as the footprint extended into the known habitat of several species of cetaceans in the GoM.

\section{DISCUSSION}

As the evidence presented here indicates, dolphins and whales do not always avoid petroleum products, as they were observed and documented swimming in different types of oil following the DWH spill, ranging from thick conspicuous oil to thin translucent sheen. Although animals were likely able to detect the thick and dark-colored patches of oil, detection of the lighter substances may have been more difficult, as suggested by previous captive and wild accounts (Geraci et al. 1983, Smultea \& Würsig 1995). Reasons to explain why cetaceans would enter contaminated waters are merely speculative, but perhaps there was some overriding behavioral motivation, such as feeding or social interactions, that induced the animals to swim through oil and sheen. In addition, avoidance may have been compounded by the magnitude of the DWH oil spill, with whales and dolphins potentially unable to leave to non-oiled regions due to the extent of the contaminated area.

Photos of dolphins with oil on their bodies not only indicate previous contact with oil but also show that oil can adhere to and persist on cetacean skin. Direct contact with petroleum products raises concerns over exposure to toxic compounds, especially in sensitive areas like the eyes, mouth, and airways as documented in Fig. 1C. This image also illustrates how oil could persist on dolphin skin even though the animal was vigorously swimming in the wake produced by the bow of the ship.

The mechanism of exposure for stranded dolphins might be different from that of free swimming cetaceans, since once ashore, animals may have encountered oil on contaminated beaches or marshes instead of floating on the water. In addition, carcasses of dead stranded animals may have come into contact with oil after the animal died. Therefore, the determination of when and how the contact with oil took place is difficult, if not impossible to make, although the oiled strandings do provide evidence that oil can adhere to the skin of stranded dolphins, live or dead. Furthermore, some of the oiled animals

Fig. 1. Direct exposure of cetaceans to petroleum products recorded during NOAA NRDA projects, spill response and monitoring activities and strandings following the Deepwater Horizon oil spill. (A) Bottlenose dolphin with oil on head, 5 August 2010 (photo: LDWF); (B) bottlenose dolphin with oil on dorsal fin, 24 June 2010 (photo: NOAA MSS NRDA Photo-ID Survey); (C) bottlenose dolphin with oil on head and dorsal fin, 11 July 2010 (photo: NOAA MaMOSAS cruise); (D) bottlenose dolphin with oil on pectoral fin, 19 June 2010 (photo: NOAA MaMOSAS cruise); (E) stranded live bottlenose dolphin (MCT-20100902LA002), 2 September 2010 (photo: LDWF); (F) striped dolphins swimming through oil, 29 April 2010 (photo: NOAA Helicopter Survey); (G) sperm whales swimming through oil, 28 April 2010 (photo: NOAA Helicopter Survey); and (H) rough-toothed dolphins swimming through oil, 16 June 2010 (photo: NOAA). Not all photographs found are displayed here. Unid: unidentified; see Table 1 legend for acronym definitions. Map produced with ArcGIS® 10.3.1 


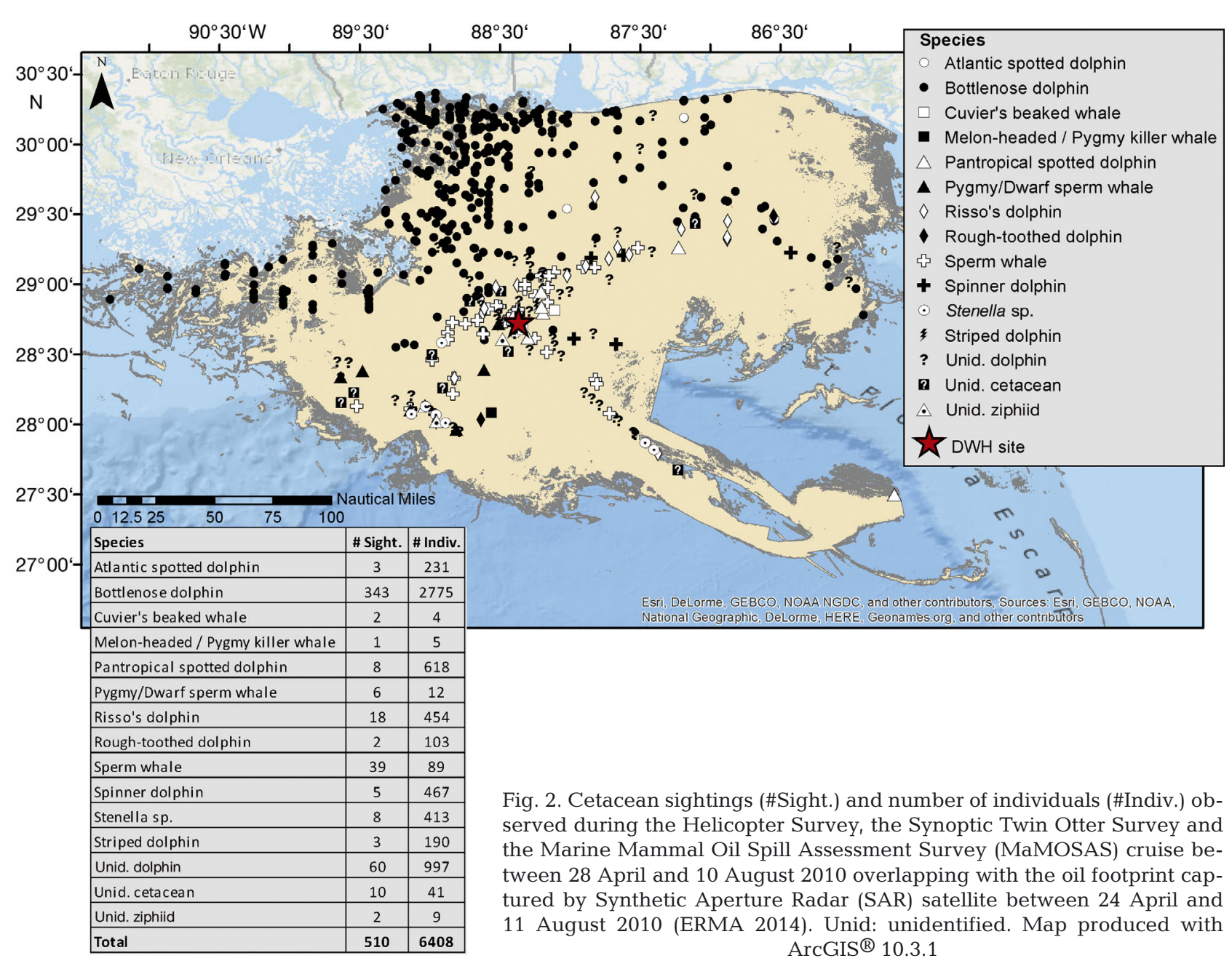

stranded 2 yr following the DWH oil spill, confirming the products' persistence in the habitat.

\section{CONCLUSIONS}

The data presented here provide evidence of direct exposure of cetaceans to petroleum products (oil and sheen) following the DWH oil spill in the GoM. Although it has been suggested in the published literature that some cetacean species are able to detect and potentially avoid different types of oil, the evidence presented here shows that cetaceans in the GoM came into direct contact with both oil and sheen by swimming through them, and by oil adhering to their skin. In addition, based on the extent of the oil footprint and its presence in cetacean habitat, the number of affected species and individuals was likely far greater than the documented occurrences captured during this study. Based on this evidence, during oil spills in cetacean habitat it should be pre- sumed that direct exposure to petroleum products will likely occur, and this should therefore be taken into account during response activities and damage assessments.

Acknowledgements. We greatly recognize the efforts of the many researchers, staff and institutions that provided support for field work and data collection during and after the DWH oil spill. Photographs used in this study were collected by the NOAA (Brenda Rone, Adam U, Ronald Wooten, Brian Stacey and other scientific crew), LDWF (Mandy Tumlin), and USCG. The LDWF and the Emerald Coast Wildlife Refuge, authorized through Letters of Authority from the National Marine Fisheries Service regional office, responded to the stranded cetaceans included in this study. We thank the scientific party and crew members of the NOAA ship 'Gordon Gunter' and aircrafts. Thanks to Jill Bodnar (ORR) and Liz Stratton (SEFSC) for providing access to additional data. We also appreciate the valuable input provided by Lori Schwacke, Laurie Sullivan, Ryan Takeshita, Keith Mullin, Eric Zolman, Brian Quigley, James Daugomah and Gina Rappucci in reviewing the manuscript. We also thank the anonymous reviewers for their editorial com- 
ments. NOAA and NCCOS activities were conducted under Marine Mammal Protection Act Permit number 779-1633. This research was carried out (in part) under the auspices of the Cooperative Institute for Marine and Atmospheric Studies (CIMAS), a Cooperative Institute of the University of Miami and the National Oceanic and Atmospheric Administration, cooperative agreement \#NA 15OAR4320064. This work was part of the DWH NRDA, being conducted cooperatively among NOAA, other federal and state Trustees, and BP PLC. The findings and conclusions in this paper are those of the authors and do not necessarily represent the view of NOAA or of any other natural resource Trustee for the BP/Deepwater Horizon NRDA.

\section{LITERATURE CITED}

Dias L, Garrison LP (2015) Distribution and abundance of cetaceans in the northern Gulf of Mexico. DWH NRDA Marine Mammal Technical Working Group Report. https:// pub-dwhdatadiver.orr.noaa.gov/dwh-ar-documents/876/ DWH-AR0106004a.pdf (accessed 7 Oct 2015)

DWH NRDA (Deepwater Horizon Natural Resource Damage Assessment) Trustees (2016) Deepwater Horizon oil spill: final programmatic damage assessment and rest ration plan and final programmatic environmental impact statement. www.gulfspillrestoration.noaa.gov/restorationplanning/gulf-plan (accessed 7 Oct 2015)

Engelhardt FR (1983) Petroleum effects on marine mammals. Aquat Toxicol 4:199-217

ERMA (Environmental Response Management Application) (2014) Deepwater Gulf response. http://gomex.erma. noaa.gov/erma.html (accessed 9 Sept 2014)

Garrison LP (2011) Summary of synoptic aerial surveys for sea turtle and marine mammal assessment during the Deepwater Horizon oil spill. National Marine Fisheries Service, Southeast Fisheries Science Center. https:// pub-dwhdatadiver.orr.noaa.gov/dwh-ar-documents/879/ DWH-AR0270234.pdf (accessed 25 Nov 2015)

Geraci JR, St. Aubin DJ (1990) Sea mammals and oil: confronting the risks. Academic Press, San Diego, CA

Geraci JR, St Aubin DJ, Reisman RJ (1983) Bottlenose dolphins, Tursiops truncatus, can detect oil. Can J Fish Aquat Sci 40:1516-1522

Helm RC, Coasta DP, DeBruyn TD, O'Shea TJ, Wells RS, Williams TM (2015) Overview of effects of oil spills on

Editorial responsibility: Michael Ziccardi (Guest Editor), Davis, California, USA marine mammals. In: Fingas M (ed) Handbook of oil spill science and technology. John Wiley \& Sons, Hoboken, NJ, p 455-475

Martinez A, Garrison LP, Mullin K (2010) Cruise results, GU10-03 (59): marine mammal oil spill assessment survey (MaMOSAS). Marine Mammal Program, Southeast Fisheries Science Center, National Marine Fisheries Service. https://pub-dwhdatadiver.orr.noaa.gov/dwh-ardocuments/879/DWH-AR0265364.pdf (accessed 25 Nov 2015)

Matkin CO, Saulitis EL, Ellis GM, Olesiuk P, Rice SD (2008) On going population-level impacts on killer whales Orcinus orca following the 'Exxon Valdez' oil spill in Prince William Sound, Alaska. Mar Ecol Prog Ser 356:269-281

MMHSRP (Marine Mammal Health and Stranding Response Program) (2015) Marine mammal health and stranding response program national database. https://mmhsrp. nmfs.noaa.gov/mmhsrp/ (accessed 29 June 2015)

NOAA NRDA (National Oceanic and Atmospheric Administration Natural Resource Damage Assessment) (2015) Work plan: aerial surveys for assessing marine mammals and sea turtles in the region of the Mississippi Canyon 252 incident. https://pub-dwhdatadiver.orr.noaa.gov/dwhar-documents/875/DWH-AR0016965.pdf (accessed 25 Nov 2015)

O'Hara TM, O'Shea TJ (2001) Toxicology. In: Dierauf LA, Gulland FMD (eds) CRC handbook of marine mammal medicine, $2^{\text {nd }}$ edn. CRC Press, Boca Raton, FL, p 471-520

OWJA (Open Water Oil Identification Job Aid for aerial observation) (2007) New standardized oil slick appearance and structure nomenclature and code (updated November 2007). US Department of Commerce, National Oceanic and Atmospheric Administration, Office of Response and Restoration, Emergency Response Division, Seattle, WA

Smith TG, Geraci JR, St Aubin DJ (1983) Reaction of bottlenose dolphins, Tursiops truncatus, to a controlled oil spill. Can J Fish Aquat Sci 40:1522-1525

Smultea MA, Würsig B (1995) Behavioral reactions of bottlenose dolphins to the Mega Borg oil spill, Gulf of Mexico 1990. Aquat Mamm 21:171-181

Stout SA (2015) Chemical fingerprinting assessment of exposure of dolphins to Macondo oil during and after the Deepwater Horizon oil spill. DWH Natural Resource Exposure NRDA Technical Working Group Report. https:// pub-dwhdatadiver.orr.noaa.gov/dwh-ar-documents/946/ DWH-AR0038954.pdf (accessed 25 Nov 2015)

Submitted: May 2, 2016; Accepted: September 7, 2016

Proofs received from author(s): November 1, 2016 